\title{
Original Research \\ Assessment of Arsenic Contamination in and around a Plateau Lake: Influences of Groundwater and Anthropogenic Pollution
}

\author{
Ping-Ping Zhang ${ }^{1,2}$, Shuang-Shuang Lyu ${ }^{3}$, Xu-Heng Zhu', \\ Xue-Gang Chen ${ }^{1,2 *}$, Dai-Dai $\mathrm{Wu}^{4}$, Ying $\mathrm{Ye}^{1}$ \\ 'Ocean College, Zhejiang University, Zhoushan 316021, P R China \\ ${ }^{2}$ State Key Laboratory of Satellite Ocean Environment Dynamics, Second Institute of Oceanography, \\ State Oceanic Administration, Hangzhou 310012, P R China \\ ${ }^{3}$ Zhejiang Institute of Geology and Mineral Resources, Hangzhou 310007, P R China \\ ${ }^{4}$ Guangzhou Institute of Energy, China Academy of Science, Guangzhou 510640, P R China
}

Received: December 9, 2014

Accepted: September 3, 2015

\begin{abstract}
Yangzonghai Lake is a typical fault-controlled highland lake in China. In this study, we investigated the occurrence and behavior of Arsenic in and around the lake. The As concentrations of lakeside sediment, lacustrine sediment, and soil samples were $20-70 \mathrm{mg} \cdot \mathrm{kg}^{-1}$. Ascribed to the geochemical accumulation and anthropogenic contamination, soil, lakeside sediment, and lacustrine sediment showed gradually increased correlation coefficients between As and heavy metals. Arsenic in and around the lake was influenced by both groundwater and human pollution. The sinters of groundwater showed high concentrations of As $\left(>150 \mathrm{mg} \cdot \mathrm{kg}^{-1}\right), \mathrm{Sb}$, and $\mathrm{Hg}$, while the chemical waste and slope deposit samples from the pollution industry exhibited elevated concentrations of all heavy metals (As, $170-370 \mathrm{mg} \cdot \mathrm{kg}^{-1}$ ). The enrichment factors (EF) of the samples suggest that the soil and lacustrine sediment samples were relatively unpolluted with As enrichment of $<10$, while the sinters and chemical wastes showed extremely high EF values of $>200$. Most samples can be classified into groups 1,2, and 3 that were affected by groundwater, indicating that the influence of groundwater on the As occurrence was more intensive than that of the pollution industry. The influence of human pollution was quite limited and localized. This study suggests that groundwater is an essential factor that should be taken into consideration when assessing the As contamination in fault-related plateau lakes.
\end{abstract}

Keywords: Arsenic, sediment, groundwater, anthropogenic pollution, Yangzonghai Lake

\section{Introduction}

Arsenic has attracted great interests from scientists and governments due to its high toxicity and ubiquitous occurrence in the environment. People who are chronically exposed to As through oral, dermal, or respiration may develop serious diseases (e.g., Black foot disease) and the

*e-mail: chenxg83@zju.edu.cn risks of cancers may increase [1-3]. Arsenic is globally presented in the Earth's crust, including soils, sediments, water bodies, and rocks [4-6]. Arsenic occurs in more than 200 types of minerals, which mostly are ore minerals or the alteration products of ore minerals [7]. Some sulfide minerals such as pyrite, marcasite, and sphalerite may even contain As with concentrations of higher than $10,000 \mathrm{mg} \cdot \mathrm{kg}^{-1}$ [7]. Arsenic occurrence in soils, sediments, and rocks may be largely caused by these As-rich minerals $[8,9]$. On the 
other hand, the As-bearing minerals may also increase the As concentration in groundwater, and consequently cause many endemic diseases. For instance in Bangladesh, groundwater with high As content has threatened the health of millions of people, where the As was mainly derived from sediments in addition to human pollution $[8,10,11]$.

The sources of As in the environment can be classified as anthropogenic inputs and natural releases. The anthropogenic sources include discharge of industrial wastewaters $[12,13]$, combustion of fossil fuels [14], and production and use of As-bearing chemicals such as herbicides, pesticides, and crop desiccants [15]. The natural inputs of As include weathering and erosion of As-bearing minerals and rocks, hydrothermal emanations, and volcanic eruptions $[7,16]$. Arsenic will be released from As-bearing sulfides into groundwater under oxidizing conditions, and inversely As will precipitate as sulfide into sediment or clays under reduction conditions $[8,17]$. In addition, the weathering and alteration of As-bearing minerals and rocks will also release As into the environment [7, 18, 19]. Therefore, it is essential to study As occurrence in soils, sediments, and so on to fully understand the contamination and source of As in a specific area.

Yangzonghai Lake is a typical fault-controlled plateau lake in Yunnan province, China. In June 2008, the As con- centration of the lake water increased dramatically from less than $0.005 \mathrm{mg} \cdot \mathrm{L}^{-1}$ to higher than $0.1 \mathrm{mg} \cdot \mathrm{L}^{-1}[20]$. Although the lake water has been treated and the As concentration has been decreased to orginal levels $\left(<0.01 \mathrm{mg} \cdot \mathrm{L}^{-1}\right)$, this lake is still particularly important for scientists and local governments to study the sources, behaviors, and fate of As in plateau lakes. For example, Wang et al. [20] studied the As concentrations in the lacustrine sediment, lake water, and aquatic organisms, and investigated the risk of As pollution in Yangzonghai Lake. Zhang et al. [21-23] studied the As concentrations in lake water and lake sediments, and assessed the pollution level by calculating the geoaccumulation indexes. Qi et al. [24] investigated the source and speciation of As in this lake, and suggested that As in the lake was mainly polluted by the chemical industry.

These studies, however, lacked in-depth assessment of As enrichment in the lake, and the As occurrence around the lake is still unknown. In this study we collected various samples, including altered volcanic rocks, lacustrine sediments, lakeside sediments, soils, slope deposits, and chemical wastes of a phosphate plant in and around Yangzonghai Lake. We analyzed the distributions of Arsenic and related trace metals in these samples, and studied the enrichments of these elements. In addition, we studied the correlation coefficients among these elements and classified these sam-

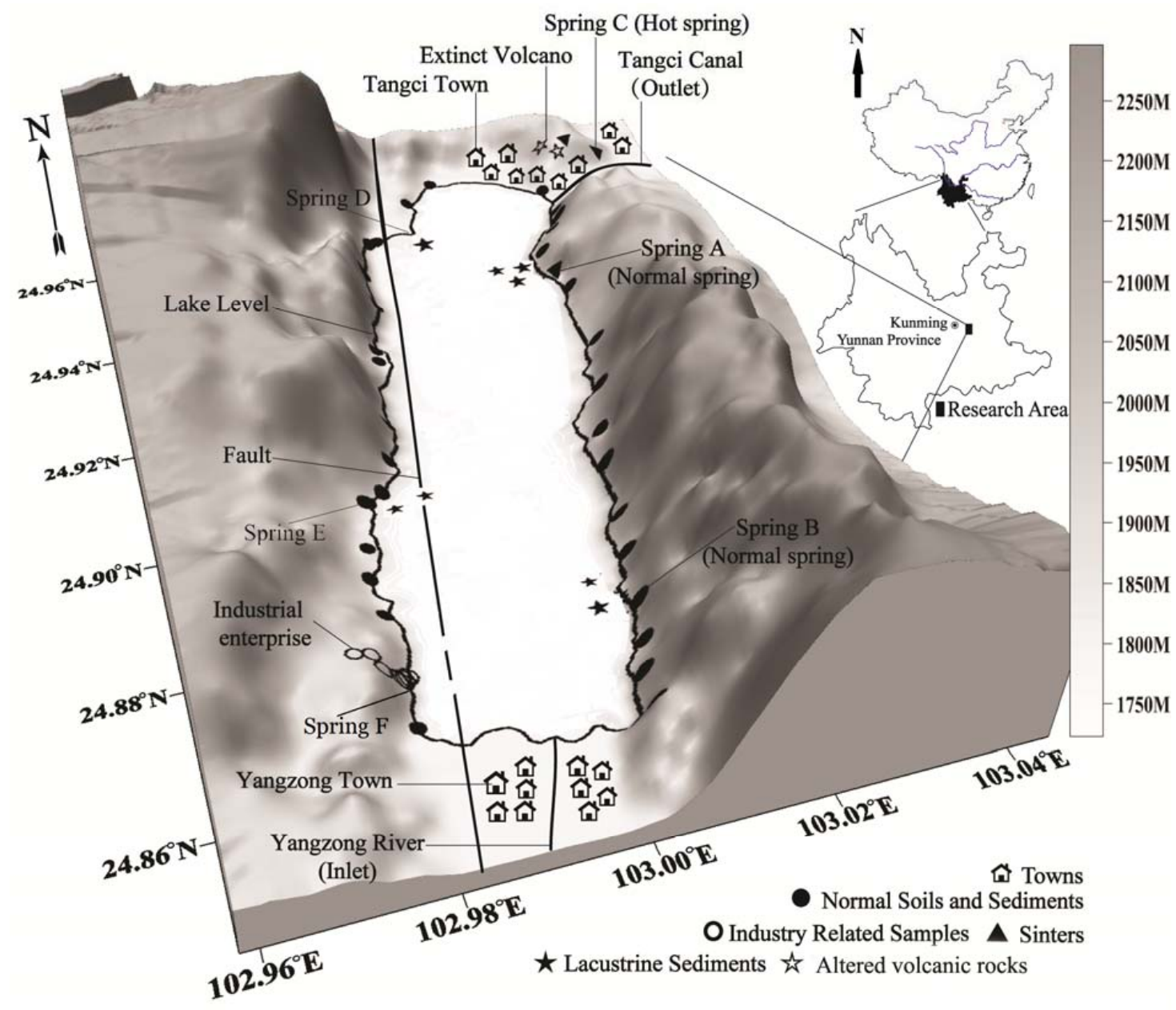

Fig. 1. Geographical position and geological setting of Yangzonghai Lake. The sample locations are shown in various symbols according to the types of obtained samples. 
ples by hierarchical cluster analysis. We further suggested the potential factors that controlled the distribution and enrichment of As in and around the lake.

\section{Field Descriptions}

The studied area - Yangzonghai Lake - is a fault-controlled freshwater lake located in Yiliang County, Yunnan province, China (Fig. 1). The geographical location of the rod-shaped lake is between $102^{\circ} 55^{\prime}$ and $103^{\circ} 02^{\prime}$ longitude and $24^{\circ} 27^{\prime}$ and $24^{\circ} 54^{\prime}$ latitude, with a length of about $12 \mathrm{~km}$ and width of $3 \mathrm{~km}$. Xiaojiang fault developed along the north-south direction of the lake. The major water supply is groundwater, which discharges from various springs that ubiquitously surround the lake. Important springs A, B, C, $\mathrm{D}, \mathrm{E}$, and $\mathrm{F}$ with large runoffs are marked on Fig. 1. In addition to meteoric water, the major surface water input is Yangzong River that flows through Yangzong city and recharges water to the south of the lake. The main output is Tangci Canal at the north end of the lake. A phosphate fertilizer plant is located along the southwest bank of the lake, but it has been closed by the local government who proposed that this plant polluted the lake water in 2008 by discharging a large amount of As-bearing wastewater into the lake.

\section{Material and Methods}

\section{Sampling Methods}

Rock, sinter, soil, and lakeside sediment samples were collected by bare hands with pre-cleaned gloves. These samples were conserved in plastic bags. The lacustrine sediment samples were collected by a self-made core sampler with an inner diameter of $52 \mathrm{~mm}$ and a length of $0.9 \mathrm{~m}$. The sampling started from November 3 to November 10, 2009. The sample locations were recorded using a hand-held GPS (Fig. 1). The collected samples were separated into seven groups according to their characteristics and sample locations: altered volcanic rock (three samples), lacustrine sediment from the bottom of the lake (eight samples), lakeside sediment that near the lake bank (24 samples), sinter that formed in the springs (seven samples), slope deposit (seven samples), surface soil (17 samples), and chemical waste from the phosphate plant (four samples).

\section{Determination of the Elements}

The concentrations of $\mathrm{As}, \mathrm{Sb}, \mathrm{Hg}$, and $\mathrm{Bi}$ in the samples were analyzed by atomic fluorescence spectroscopy (AFS) (model: AF-610A, Beijing Rayleigh Analytical Instrument Co., Beijing, China). The operating conditions were maintained as follows: negative high voltage of $270 \mathrm{~V}$, atomizer height of $8 \mathrm{~mm}$, air flow rate of $300 \mathrm{~mL} \cdot \mathrm{min}^{-1}$, lamp current of $30 \mathrm{~mA}$, atomization temperature of $170^{\circ} \mathrm{C}$, and recording time of $18 \mathrm{~s}$. The concentrations of $\mathrm{Fe}, \mathrm{Mn}$, and $\mathrm{Al}$ were determined using an X-ray fluorescence spectrometer (XRF) (model: SPECTRO XEPOS XEP01, Spectro
Analytical instruments, Germany). The operating voltage and current were maintained at $50 \mathrm{kV}$ and $50 \mathrm{~mA}$, respectively. The contents of $\mathrm{Pb}, \mathrm{Zn}, \mathrm{Ni}, \mathrm{Cd}$, and $\mathrm{Co}$ were determined by inductively coupled plasma-mass spectrometry (ICP-MS) (model: $7500 \mathrm{CE}$, Agilent, USA) with operating conditions of 1,350 $\mathrm{W}$ in RF Power, $6.0 \mathrm{~mm}$ sampling depth, $1.02 \mathrm{~L} \cdot \mathrm{min}^{-1}$ carrier gas $(\mathrm{Ar})$, and $4.5 \mathrm{~mL} \cdot \mathrm{min}^{-1}$ helium flow rate. Reagent blanks, duplicate samples, and reference materials (Dorm-2, Dogfish muscle, NRC, Canada) were used for quality control. The estimated error as a relative standard deviation was between $2 \%$ and $8 \%$.

\section{Data Analyses}

The correlation and cluster analyses were conducted by software SPSS (version 19.0 for Windows). The bivariate correlations were calculated using Pearson correlation coefficients with a two-tailed test of significance. Prior to cluster analysis, the elements were reduced to three factors using factor analysis by extracting principal components. The obtained three factors were subsequently hierarchically clustered by Ward's method with squared Euclidean distance as the interval.

\section{Results and Discussion}

\section{Heavy Metal Distributions of the Samples}

The collected samples were analyzed to study their heavy metal concentrations and distributions. The elemental concentrations varied greatly with the types of samples (Fig. 2). Lacustrine sediment, lakeside sediment, and soil samples showed comparable elemental distributions with average heavy metal concentrations of: As $20-70 \mathrm{mg} \cdot \mathrm{kg}^{-1}$, Sb 1.4-2.0 mg $\mathrm{kg}^{-1}, \mathrm{~Pb} 32-48 \mathrm{mg} \cdot \mathrm{kg}^{-1}$, Fe 4.2-6.9 $\mathrm{mg} \cdot \mathrm{kg}^{-1}$, Mn 420-660 mg.kg-1, Zn 100-120 mg $\mathrm{kg}^{-1}$, Co $16-6 \mathrm{mg} \cdot \mathrm{kg}^{-1}$, $\mathrm{Cd} 0.6-0.8 \mathrm{mg} \cdot \mathrm{kg}^{-1}$, and $\mathrm{Hg} 0.16-0.25 \mathrm{mg} \cdot \mathrm{kg}^{-1}$. It is suggested that they might have originated from the same sources, because surface runoff may flush the soil into the lake bank and form lakeside sediment; subsequently the lakeside sediment may deposit onto the bottom of the lake and form lacustrine sediment. The sinter samples that deposited from the spring water presented high As $\left(158 \mathrm{mg} \cdot \mathrm{kg}^{-1}\right), \mathrm{Sb}$ (10 $\left.\mathrm{mg} \cdot \mathrm{kg}^{-1}\right)$, and $\mathrm{Hg}\left(16 \mathrm{mg} \cdot \mathrm{kg}^{-1}\right)$ concentrations, but extremely low contents of all other heavy metals. This is attributed to the fact that groundwater in the Yangzonghai area was rich in $\mathrm{As}, \mathrm{Sb}$, and $\mathrm{Hg}$ [20]. The altered volcanic rock showed similar elemental distributions to that of sinter except for the relatively lower As contents $\left(43.7 \mathrm{mg} \cdot \mathrm{kg}^{-1}\right)$. The geochemistry of metamorphic rock is greatly determined by its precursor and therefore the volcanic rocks in this area should contain high contents of chalcophile elements, which is common due to the vast presence of sulfide-rich magmas [25]. The As therein may be leached out by waster during metamorphism. The slope deposit and chemical waste samples showed similar chemical compositions with high contents of heavy metals, including As $\left(175-370 \mathrm{mg} \cdot \mathrm{kg}^{-1}\right), \mathrm{Sb}\left(\sim 8 \mathrm{mg} \cdot \mathrm{kg}^{-1}\right), \mathrm{Pb}\left(\sim 190 \mathrm{mg} \cdot \mathrm{kg}^{-1}\right)$, 
Table 1. Comparisons on the As concentrations in the lake sediment between Yangzonghai and other lakes.

\begin{tabular}{|l|l|c|c|c|}
\hline \multicolumn{1}{|c|}{ Lake } & As concentrations $\left(\mathrm{mg} \cdot \mathrm{kg}^{-1}\right)$ & Source of As & Source \\
\hline \multirow{4}{*}{$\begin{array}{l}\text { Plateau lake } \\
\text { in Yunnan, } \\
\text { China }\end{array}$} & Yangzonghai Lake & $20-70$ & Natural source and human pollution & This study \\
\cline { 2 - 5 } & Yilong lake & $8-26$ & Human pollution & {$[26]$} \\
\cline { 2 - 5 } & Yungui plateau lakes & $7-41$ (average 14.2) & Natural source & {$[27]$} \\
\cline { 2 - 5 } & Dianchi & $12-169$ & Human pollution & {$[31]$} \\
\hline & Freshwater lakes in East China plain & $5-18$ & unknown & {$[28]$} \\
\cline { 2 - 5 } & Lake Cildir, Turkey & $1.5-3.8$ & unknown & {$[29]$} \\
\cline { 2 - 5 } & Lake Geneva, Switzerland & $6-16$ & Human pollution & {$[30]$} \\
\hline
\end{tabular}

Zn (500-1,000 $\left.\mathrm{mg} \cdot \mathrm{kg}^{-1}\right), \mathrm{Cd}\left(4-7 \mathrm{mg} \cdot \mathrm{kg}^{-1}\right)$, and $\mathrm{Hg}(1.2-4.2$ $\left.\mathrm{mg} \cdot \mathrm{kg}^{-1}\right)$. Because most slope deposit samples were collected near the phosphate plant where we also sampled the chemical wastes, the similarity between slope deposits and chemical waste samples should be attributed to the contamination of the phosphate plant. The extremely high concentrations of $\mathrm{As}, \mathrm{Pb}, \mathrm{Zn}, \mathrm{Cd}$, and $\mathrm{Hg}$ in the chemical waste confirmed the severe pollution of this chemical industry. Compared with sinter samples, the chemical wastes exhibit comparable concentrations of $\mathrm{Sb}$ and $\mathrm{Hg}$, doubled $\mathrm{As}$ contents, and much higher concentrations of $\mathrm{Pb}, \mathrm{Zn}, \mathrm{Co}$, and $\mathrm{Cd}$ - reflecting the different characteristics of heavy metals contributed by groundwater and the phosphate plant.
Table 1 shows the comparisons on the As concentrations in the sediment between Yangzonghai Lake and other lakes. Arsenic concentrations in the lake sediments of Yangzonghai are significantly higher than that of other Yungui plateau lakes, where As mainly originated from natural sources $[26,27]$. It is indicated that either groundwater or human pollution elevated the As contents in Yangzonghai Lake sediments. The As contents in Yangzonghai are also higher than that in freshwater lakes of the East China plain, Lake Cildir in Turkey, and Lake Geneva [28-30]. The As concentrations in the sediments from Lake Dianchi, however, are generally higher than that of this study, because Dianchi is located near Kunming and was severely polluted [31].
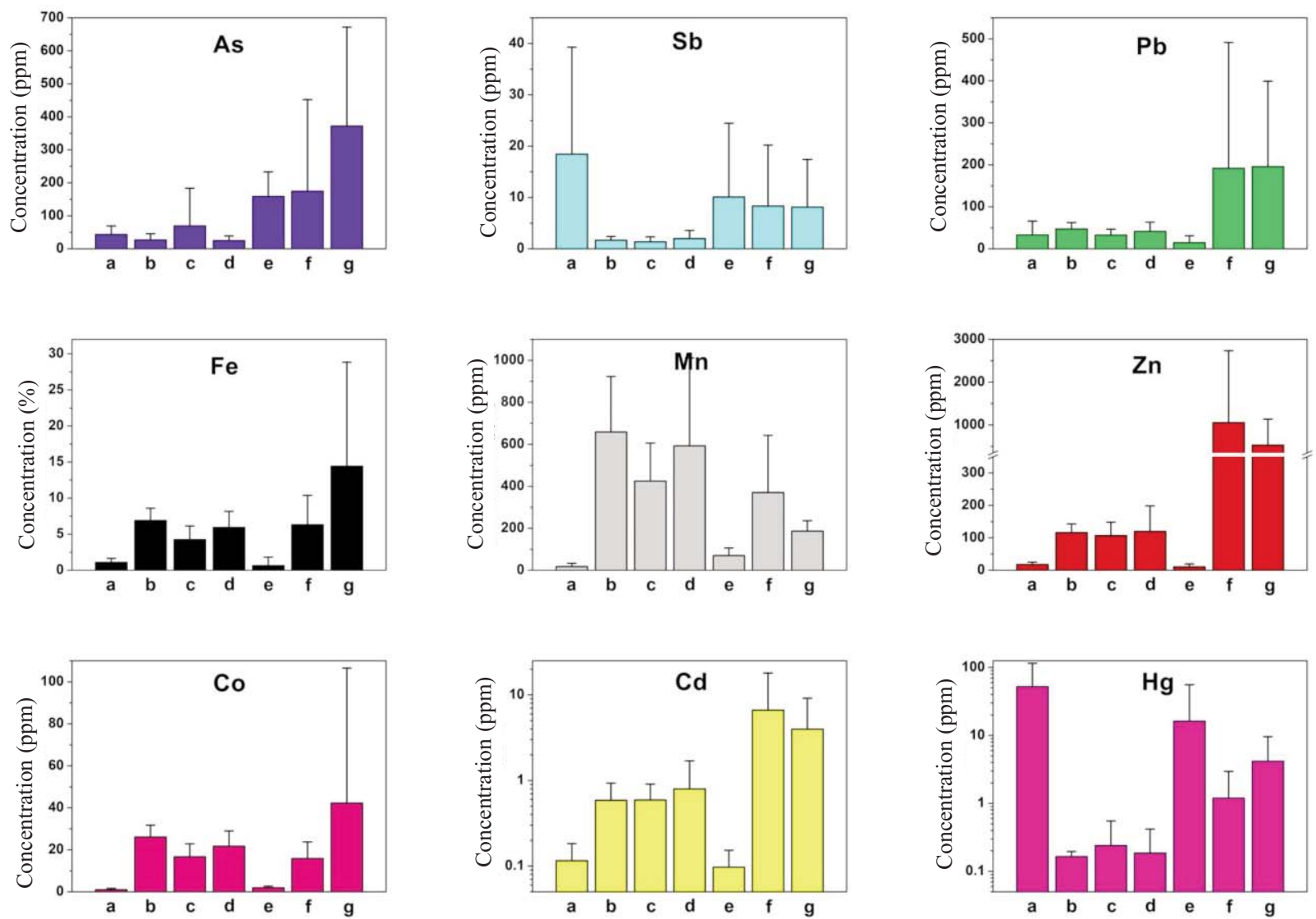

Fig. 2. Average elemental concentrations of different types of samples: (a) altered volcanic rock, (b) lacustrine sediment, (c) lakeside sediment, (d) soil, (e) sinter, (f) slope deposit, and (g) chemical waste. 
Table 2. Pearson correlation coefficients among elements of obtained samples.

\begin{tabular}{|c|c|c|c|c|c|c|c|c|c|c|c|c|}
\hline & As & $\mathrm{Sb}$ & $\mathrm{Hg}$ & $\mathrm{Bi}$ & $\mathrm{Al}$ & $\mathrm{Fe}$ & $\mathrm{Mn}$ & $\mathrm{Ni}$ & $\mathrm{Zn}$ & $\mathrm{Pb}$ & $\mathrm{Co}$ & $\mathrm{Cd}$ \\
\hline As & 1 & & & & & & & & & & & \\
\hline $\mathrm{Sb}$ & $0.526^{* *}$ & 1 & & & & & & & & & & \\
\hline $\mathrm{Hg}$ & 0.102 & $0.502 * *$ & 1 & & & & & & & & & \\
\hline $\mathrm{Bi}$ & $0.763 * *$ & $0.465^{* *}$ & 0.027 & 1 & & & & & & & & \\
\hline $\mathrm{Al}$ & 0.000 & -0.075 & $-0.243 *$ & 0.182 & 1 & & & & & & & \\
\hline $\mathrm{Fe}$ & $0.422 * *$ & 0.063 & -0.120 & $0.234 *$ & $0.409 * *$ & 1 & & & & & & \\
\hline $\mathrm{Mn}$ & -0.215 & $-0.275^{*}$ & $-0.239 *$ & -0.101 & $0.465^{* *}$ & $0.326^{* *}$ & 1 & & & & & \\
\hline $\mathrm{Zn}$ & $0.695^{* *}$ & $0.490 * *$ & -0.013 & $0.763 * *$ & $0.291^{*}$ & $0.309 * *$ & -0.025 & 0.115 & 1 & & & \\
\hline $\mathrm{Pb}$ & $0.775^{* *}$ & $0.502 * *$ & -0.003 & $0.863 * *$ & $0.258^{*}$ & $0.411 * *$ & -0.021 & 0.209 & $0.937 * *$ & 1 & & \\
\hline Co & 0.183 & -0.152 & -0.191 & -0.036 & $0.270^{*}$ & $0.926^{* *}$ & $0.389 * *$ & $0.954 * *$ & 0.047 & 0.145 & 1 & \\
\hline $\mathrm{Cd}$ & $0.708 * *$ & $0.491 * *$ & -0.007 & $0.796^{* *}$ & $0.263^{*}$ & 0.299 ** & -0.032 & 0.108 & $0.982^{* *}$ & $0.959 * *$ & 0.035 & 1 \\
\hline
\end{tabular}

The number of value (n) for each data set is 76 .

**Correlation is significant at the 0.01 level.

*Correlation is significant at the 0.05 level.

Bold means strong correlation between As and other elements.

\section{Correlations between As and Heavy Metals}

In natural conditions, As is usually positively correlated with $\mathrm{Sb}, \mathrm{Hg}$, and $\mathrm{Pb}$ due to their analogous geochemical behaviors [26], and $\mathrm{Fe}$ and $\mathrm{Mn}$ ascribed to the adsorption of As by metal oxides $[4,7]$. Therefore, it is important to study the correlations between As and these elements to investigate the behaviors and potential sources of As in the samples. As shown in Table 2, As is strongly positively correlated with $\mathrm{Sb}, \mathrm{Bi}, \mathrm{Fe}, \mathrm{Zn}, \mathrm{Pb}$, and $\mathrm{Cd}$, with significant correlation at the 0.01 level, consistent with the above statement.

However, these results were calculated based on the data of all samples, while the correlation coefficients may vary with the types of the samples. As shown in Fig. 3, As shows low correlations with all other heavy metals in both soil and sinter samples. In contrast, As shows strong positive correlations with almost all elements in the slope deposit and chemical waste samples. These phenomena were partly attributed to the low quantities of both types of samples, and partly ascribed to the fact that most slope deposit samples were polluted by the phosphate plant where the chemical waste (with relatively constant chemical compositions) was produced. Arsenic (As) shows moderate correlation $\left(\mathrm{r}^{2}\right.$ value of 0.317$)$ with $\mathrm{Sb}$ in the lakeside sediments, and the value was increased to 0.975 in the lacustrine sediments. In addition, As exhibits moderate correlations with $\mathrm{Zn}, \mathrm{Cd}$, and $\mathrm{Fe}$ in the lacustrine sediments and low correlation in the lakeside sediments. The enhanced correlation coefficients in the lacustrine sediments than those in the lake sediments can be explained as follows. First, the lakeside sediment was mainly formed from soil through flushing of surface water, while the lacustrine sediment was generated from lakeside sediment via sedimentation. During these processes, $\mathrm{As}$ and $\mathrm{Sb}$ acted coherently due to their analogous geochemical behaviors and their correlations were gradually increased in the sediments. Second, the groundwater and human pollution will discharge heavy metals (such as As, Zn, and Cd) into the lakeside sediment and lacustrine sediment. The correlations between As and these elements were enhanced as a result. Third, arsenic adsorption by hydrous metal oxides is only significant in aqueous systems. Therefore, the correlation between $\mathrm{As}$ and $\mathrm{Fe}$ was increased in the lacustrine sediments. Note that all samples except for the slope deposits and chemical wastes show extremely low correlation coefficients between $\mathrm{As}$ and $\mathrm{Pb}$, indicating that the high correlation between them in Table 2 was probably merely a coincidence.

\section{Enrichment Factors of Arsenic and Heavy Metals}

Enrichment factor (EF) was widely used to assess the relative enrichment and contamination of heavy metals in sediments and soils [32]. Aluminum was commonly used as the reference element to calculate the EF values of heavy metals due to its conservative behavior during geochemical processes [33]. The EF value was calculated using the following equation:

$$
E F=\left(C_{M} / C_{A l}\right)_{\text {sample }} /\left(C_{M} / C_{A l}\right)_{\text {background }}
$$

...where $C_{M}$ and $C_{A l}$ are the contents of assessed metal and aluminum, respectively. The average elemental concentrations of soils of Yunnan province were selected as the background values, which are As concentration of $10.8 \mathrm{mg} \cdot \mathrm{kg}^{-1}$, $\mathrm{Sb} 1.75 \mathrm{mg} \cdot \mathrm{kg}^{-1}$, Bi $0.52 \mathrm{mg} \cdot \mathrm{kg}^{-1}$, Fe 4.55\%, Al 8.56\%, Zn $80.5 \mathrm{mg} \cdot \mathrm{kg}^{-1}, \mathrm{~Pb} 36 \mathrm{mg} \cdot \mathrm{kg}^{-1}$, and $\mathrm{Cd} 0.1035 \mathrm{mg} \cdot \mathrm{kg}^{-1}$.

Fig. 4 shows the EF values of $\mathrm{As}, \mathrm{Sb}, \mathrm{Pb}$, and $\mathrm{Cd}$ in the Yangzonghai samples. Although the EF values may be not suitable to assess the sinter, rock, and chemical waste sam- 
ples, their relative EF values can reflect the accumulation of heavy metals in these samples. Arsenic was significantly enriched $(E F>2)$ in most of the samples, including all altered volcanic rocks, $80 \%$ lakeside sediments, all sinter, $5 / 7$ slope deposit samples, and all of the chemical waste samples from the phosphate plant. The lakeside sediment and slope deposit samples showed comparable EF values of 1-55, while the chemical waste and sinter samples exhibited extremely high As enrichments with maximum EF values of higher than 200 . Note that the sinters that deposited from spring water presented 30 times higher EF values than those of chemical wastes, suggesting that groundwater may

a)

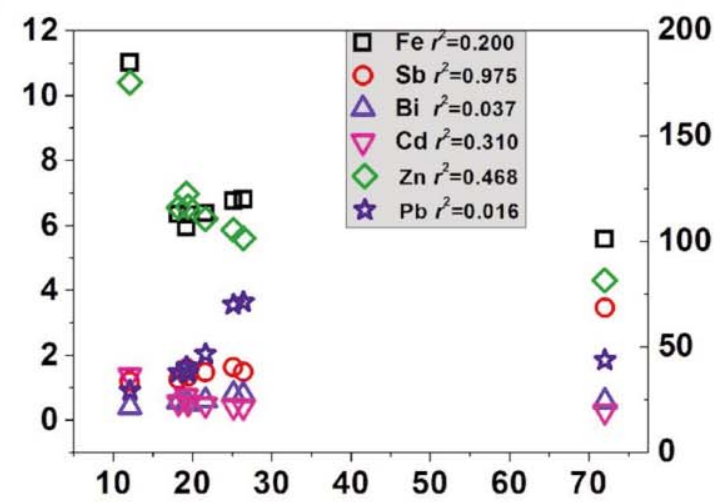

c)

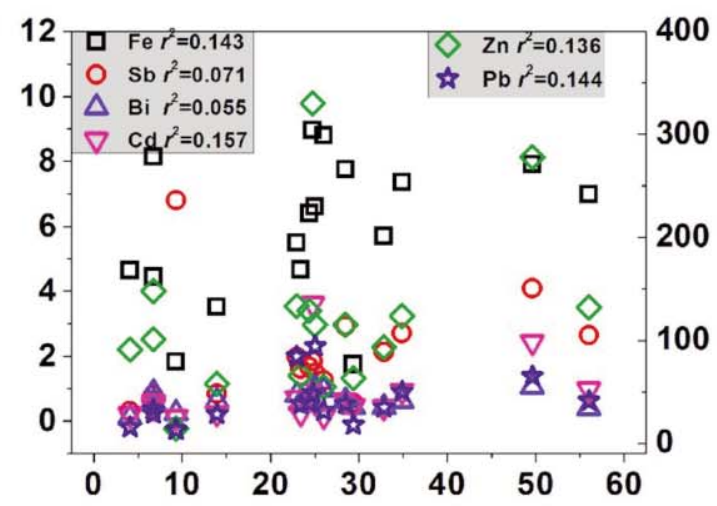

e)

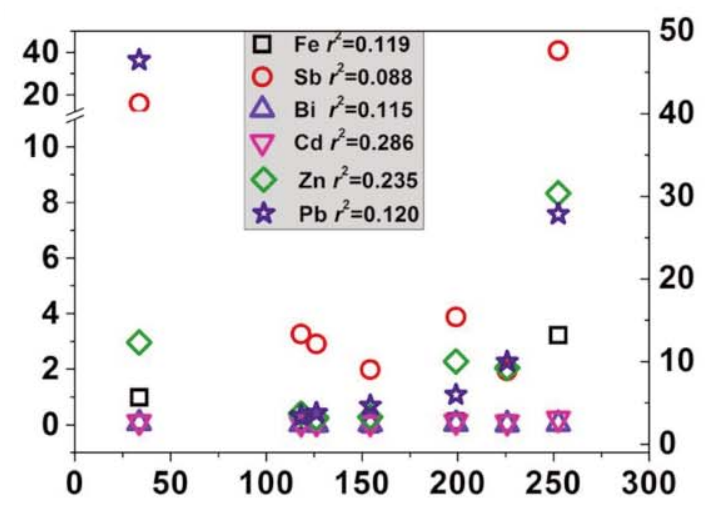

even possess higher capacity of As pollution. Only 25\% of lacustrine sediment samples and nearly $2 / 3$ soil samples exhibited $\mathrm{EF}$ values of $>2$, and the maximum $\mathrm{EF}$ values were less than 10 - much lower than that of other samples. The EF values of As in the soil samples were close to those of reference soils, suggesting that the soil in the Yangzonghai area was relatively unpolluted. The groundwater or chemical pollution subsequently increased the As enrichment in the lakeside sediments. The As enrichment in the lacustrine sediments was recovered to less than five, because As in the sediment may be released into lake water under reduction conditions $[4,8]$.

b)

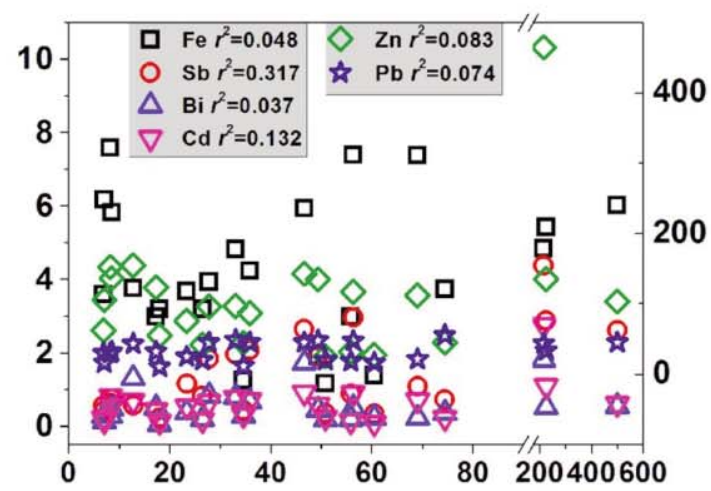

d)

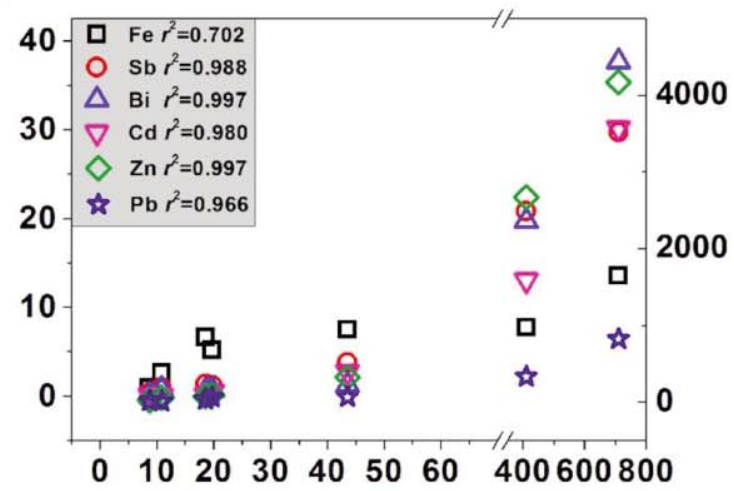

f)

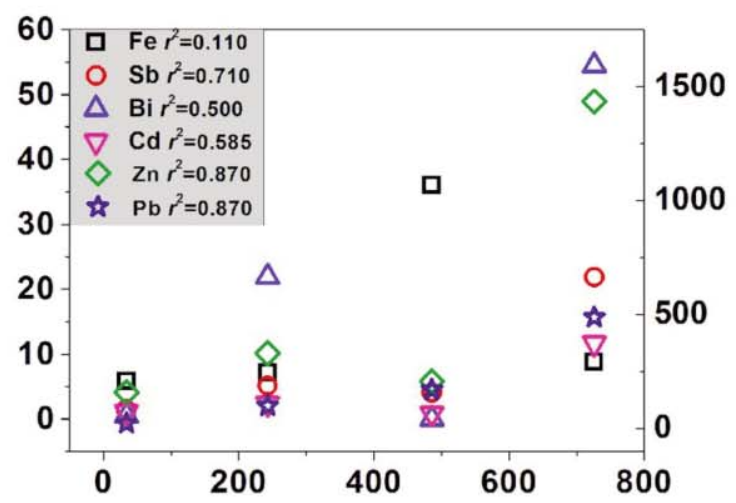

Fig. 3. Correlations between $\mathrm{As}$ and $\mathrm{Fe}, \mathrm{Sb}, \mathrm{Bi}, \mathrm{Cd}, \mathrm{Zn}$, and $\mathrm{Pb}$ in: (a) lacustrine sediment, (b) lakeside sediment, (c) soil, (d) slope deposit, (e) sinter, and (f) chemical waste samples. The horizontal coordinate, left vertical coordinate, and right vertical coordinate for all of the patterns are As concentration $\left(\mathrm{mg} \cdot \mathrm{kg}^{-1}\right)$, concentrations of heavy metals $\left(\mathrm{mg} \cdot \mathrm{kg}^{-1}\right)$, and concentrations of $\mathrm{Pb}$ and $\mathrm{Zn}\left(\mathrm{mg} \cdot \mathrm{kg}^{-1}\right)$, respectively. 


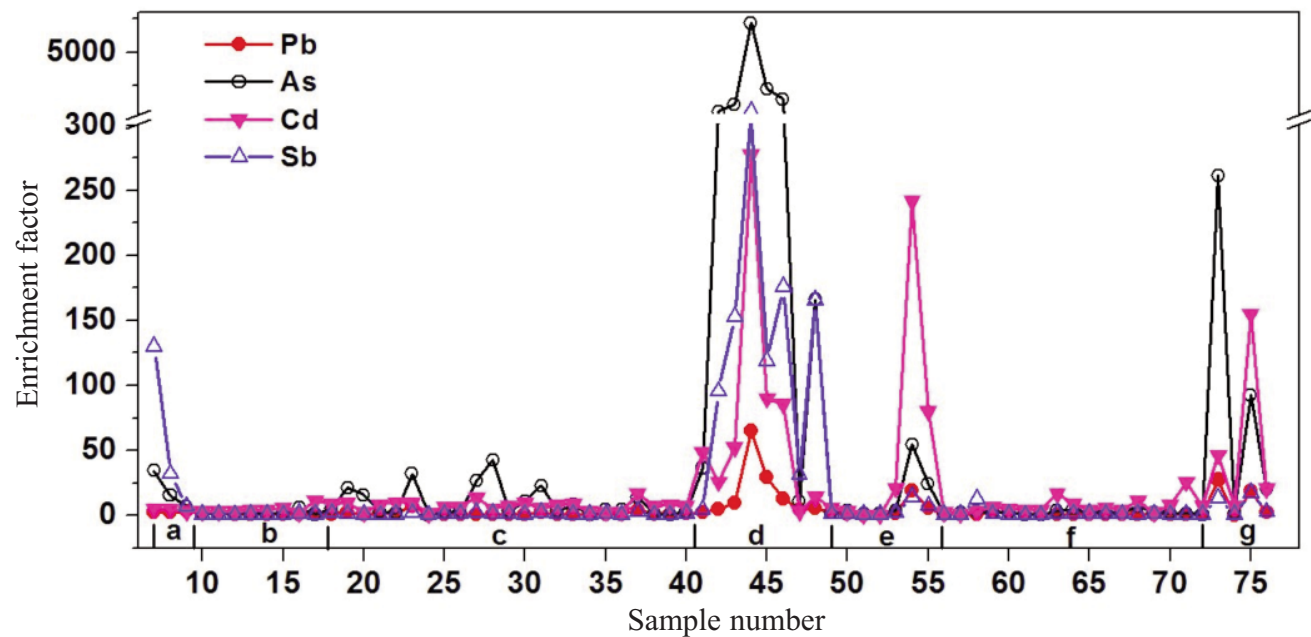

Fig. 4. Enrichment factors of $\mathrm{As}, \mathrm{Sb}, \mathrm{Pb}$, and $\mathrm{Cd}$ in: (a) altered volcanic rock, (b) lacustrine sediment, (c) lakeside sediment, (d) sinter, (e) slope deposit, (f) soil, and (g) chemical waste from the phosphate plant.

$\mathrm{Sb}$ and $\mathrm{Pb}$ were dramatically enriched in sinter, slope deposit, and chemical waste samples, and the EF values of $\mathrm{Sb}$ in sinters were orders of magnitude higher than those in chemical wastes. Therefore, groundwater around the Yangzonghai area may also contribute a large amount of $\mathrm{Sb}$ into the ambient environment. Lakeside sediments that exhibited high As enrichments did not show significant enrichments of $\mathrm{Sb}$ and $\mathrm{Pb}$, suggesting that $\mathrm{As}$ in the lakeside sediment may be additionally contaminated by groundwater or anthropogenic activities. Almost all samples presented $\mathrm{EF}$ values of $\mathrm{Cd}$ of higher than 10 . The $\mathrm{Cd}$ enrichments were higher than any other heavy metals in the slope deposit and chemical waste samples, indicating that the phosphate plant produced products or wastes with high $\mathrm{Cd}$ contents. Note that the sinter samples also showed high $\mathrm{Cd}$ enrichments, suggesting that groundwater also possess the potential of $\mathrm{Cd}$ contamination. Therefore, the high EF values of $\mathrm{Cd}$ in the lakeside sediment samples were contaminated from groundwater and the chemical industry.

\section{Cluster Analysis}

Cluster analysis is a useful method to group samples according to their common characteristics, which may determine the potential sources of heavy metals [34, 35]. Fig. 5 shows the dendrogram of the samples calculated

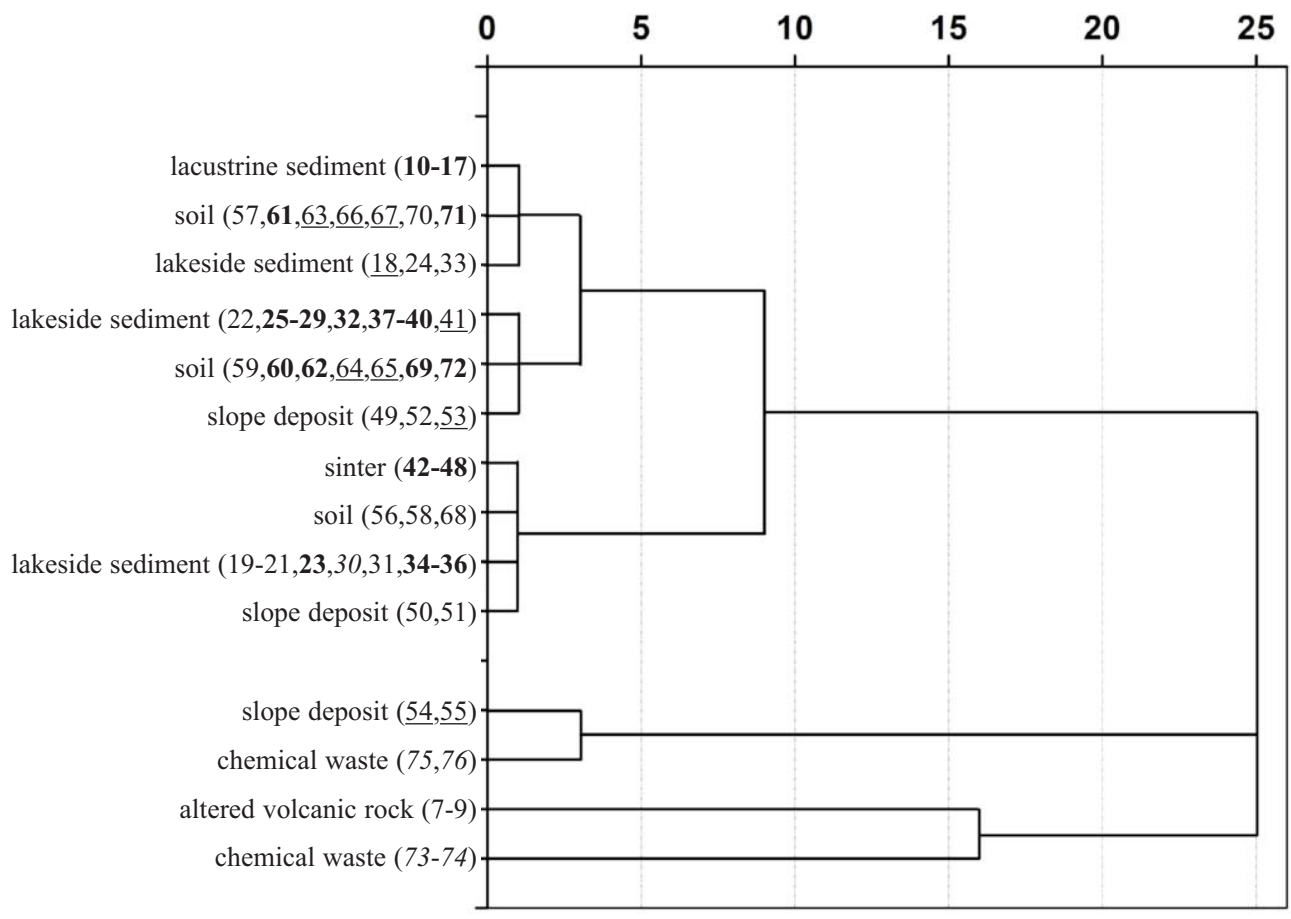

Fig. 5. Dendrogram of the samples using Ward's method. Sample numbers in italic indicate the samples were collected near the phosphate plant, bolded indicates that the sample location is near the springs, and underlined indicates that the samples was collected near both the plant and springs. 
from the hierarchical cluster analysis. The samples can be classified into five groups. All lacustrine sediment samples, seven soil samples, and three lakeside sediment samples form group 1. Most lakeside sediments (12 samples), seven soil samples, and three slope deposit samples constitute the second group. The Euclidean distance between groups 1 and 2 is 3 , suggesting that they have a close relationship. Thirtythree out of 40 samples in groups 1 and 2 were collected near springs, indicating that these samples were greatly affected by groundwater. Group 3 includes all sinter samples (7 samples), three soil samples, nine lakeside sediment samples, and two slope deposit samples. Only 11 of the total of 25 samples in group 3 were affected by springs/groundwater. The Euclidean distance between group 3 and the former two groups is enlarged to 9. Group 4 consists of two slope deposit samples that collected near both spring $\mathrm{F}$ and the phosphate plant, and two chemical waste samples from the plant. However, the internal distance between slope deposit and chemical waste samples is 3 , which is much higher than that of groups 1,2, and 3. The last cluster (group 5) includes all altered volcanic rock samples and two chemical waste samples. The internal distance is even higher - reaching a value of 16, suggesting that the relationship between altered volcanic rocks and chemical wastes is distant. All samples influenced by groundwater are included in groups 1, 2, and 3 , while $80 \%$ of samples collected near the phosphate plant belong to groups 4 and 5 . In addition, $80 \%$ of samples affected by both chemical industry and springs belong to groups 1,2, and 3. These results indicate that groundwater and chemical pollution posed distinctive influences of heavy metals on the samples, and the influence of groundwater was more intensive than that of chemical pollution from the phosphate plant. The influence of the chemical industry was quite limited and localized.

\section{Conclusion}

In summary, we investigated the occurrence and behavior of Arsenic in and around a typical fault-controlled plateau lake - Yangzonghai in China. The elemental compositions, correlation coefficients, and cluster analyses on the samples indicate that the groundwater and human activities exhibited different influences on the samples. The samples affected by groundwater presented high concentrations of chalcophile elements, including As, Sb, and $\mathrm{Hg}$, while that by the phosphate plant showed elevated concentrations of almost all heavy metals.

The As geochemistry in the soil and sediments were affected by both groundwater and the phosphate plant, and the groundwater induced higher As enrichment than that of the plant. In addition, the groundwater influence was more intensive than that of the plant. This study shows a good prototype of plateau lake, where As occurrence was affected by both natural and anthropogenic activities. Furthermore, this study indicates that groundwater is an important factor that should be considered when studying As pollution in fault-related plateau lakes.

\section{Supplementary Materials}

Original data. Elemental concentrations of the samples in and around the Yangzonghai Lake. All units are mg $\mathrm{kg}^{-1}$ except for $\mathrm{Al}$ and Fe.

\begin{tabular}{|c|c|c|c|c|c|c|c|c|c|c|c|c|c|}
\hline Location & Type & $\mathrm{Al}(\%)$ & $\mathrm{Fe}(\%)$ & $\mathrm{Mn}$ & $\mathrm{Ni}$ & $\mathrm{Zn}$ & $\mathrm{Pb}$ & As & $\mathrm{Sb}$ & $\mathrm{Hg}$ & $\mathrm{Bi}$ & $\mathrm{Co}$ & $\mathrm{Cd}$ \\
\hline \multirow{2}{*}{$\begin{array}{l}\text { 1. valley } \\
\text { N24.9428, E103.0192 }\end{array}$} & lakeside sediment & 1.90 & 1.17 & 224.60 & 10.32 & 25.33 & 19.74 & 50.81 & 0.35 & 0.12 & 0.18 & 6.75 & 0.23 \\
\hline & slope deposit & 6.59 & 5.19 & 802.80 & 39.46 & 97.70 & 61.07 & 19.74 & 1.21 & 0.08 & 0.68 & 22.62 & 0.46 \\
\hline \multirow{2}{*}{$\begin{array}{l}\text { 2. valley } \\
\text { N24.9511, E103.0250 }\end{array}$} & lakeside sediment & 3.03 & 1.39 & 197.80 & 13.94 & 27.59 & 16.12 & 60.47 & 0.33 & 0.03 & 0.22 & 10.64 & 0.08 \\
\hline & soil & 7.23 & 3.51 & 290.30 & 33.34 & 57.86 & 28.19 & 13.92 & 0.84 & 0.05 & 0.63 & 16.23 & 0.23 \\
\hline \multirow{3}{*}{$\begin{array}{l}\text { 3. valley } \\
\text { N24.9544, E103.0256 }\end{array}$} & lakeside sediment & 4.34 & 2.98 & 448.10 & 23.66 & 123.30 & 31.71 & 17.28 & 0.41 & 0.08 & 0.50 & 14.04 & 0.44 \\
\hline & \multirow{2}{*}{ soil } & 9.40 & 8.80 & 2100.00 & 73.06 & 54.77 & 31.06 & 26.02 & 1.25 & 0.10 & 0.96 & 32.15 & 0.16 \\
\hline & & 2.62 & 1.83 & 359.00 & 26.09 & 14.28 & 13.07 & 9.32 & 6.81 & 0.08 & 0.25 & 12.09 & 0.12 \\
\hline \multirow{5}{*}{$\begin{array}{l}\text { 4. hot spring C } \\
\text { N24.9597, E103.0356 }\end{array}$} & \multirow{5}{*}{ sinter } & 0.17 & 0.11 & 59.36 & 10.20 & 3.74 & 3.40 & 118.20 & 3.26 & 0.56 & 0.03 & 2.06 & 0.05 \\
\hline & & 0.09 & 0.04 & 51.99 & 9.72 & 3.20 & 3.80 & 126.10 & 2.91 & 0.60 & 0.01 & 1.73 & 0.06 \\
\hline & & 0.02 & 0.03 & 74.86 & 10.10 & 3.31 & 4.68 & 154.30 & 1.99 & 0.57 & 0.03 & 1.68 & 0.06 \\
\hline & & 0.08 & 0.05 & 133.00 & 10.47 & 9.25 & 9.99 & 225.80 & 1.94 & 0.99 & 0.02 & 1.91 & 0.09 \\
\hline & & 0.11 & 0.11 & 100.60 & 10.89 & 10.03 & 5.98 & 199.00 & 3.88 & 0.34 & 0.04 & 1.97 & 0.11 \\
\hline $\begin{array}{l}\text { 5. valley, N24.9850, } \\
\text { E103.0303 }\end{array}$ & lakeside sediment & 5.61 & 3.76 & 613.60 & 30.22 & 154.70 & 43.10 & 12.76 & 0.56 & 0.13 & 1.31 & 15.95 & 0.68 \\
\hline \multirow{3}{*}{$\begin{array}{l}\text { 6. slope } \\
\text { N24.9514, E103.0306 }\end{array}$} & \multirow{3}{*}{ slope deposit } & 1.84 & 0.94 & 128.60 & 12.75 & 22.99 & 10.89 & 8.73 & 0.39 & 0.07 & 0.11 & 5.49 & 0.08 \\
\hline & & 6.23 & 2.62 & 246.50 & 31.15 & 54.92 & 9.36 & 10.81 & 0.99 & 0.20 & 0.73 & 12.25 & 0.04 \\
\hline & & 10.88 & 6.64 & 147.20 & 47.12 & 72.60 & 36.04 & 18.56 & 1.38 & 0.20 & 0.64 & 10.72 & 0.06 \\
\hline
\end{tabular}


Original data. Continued

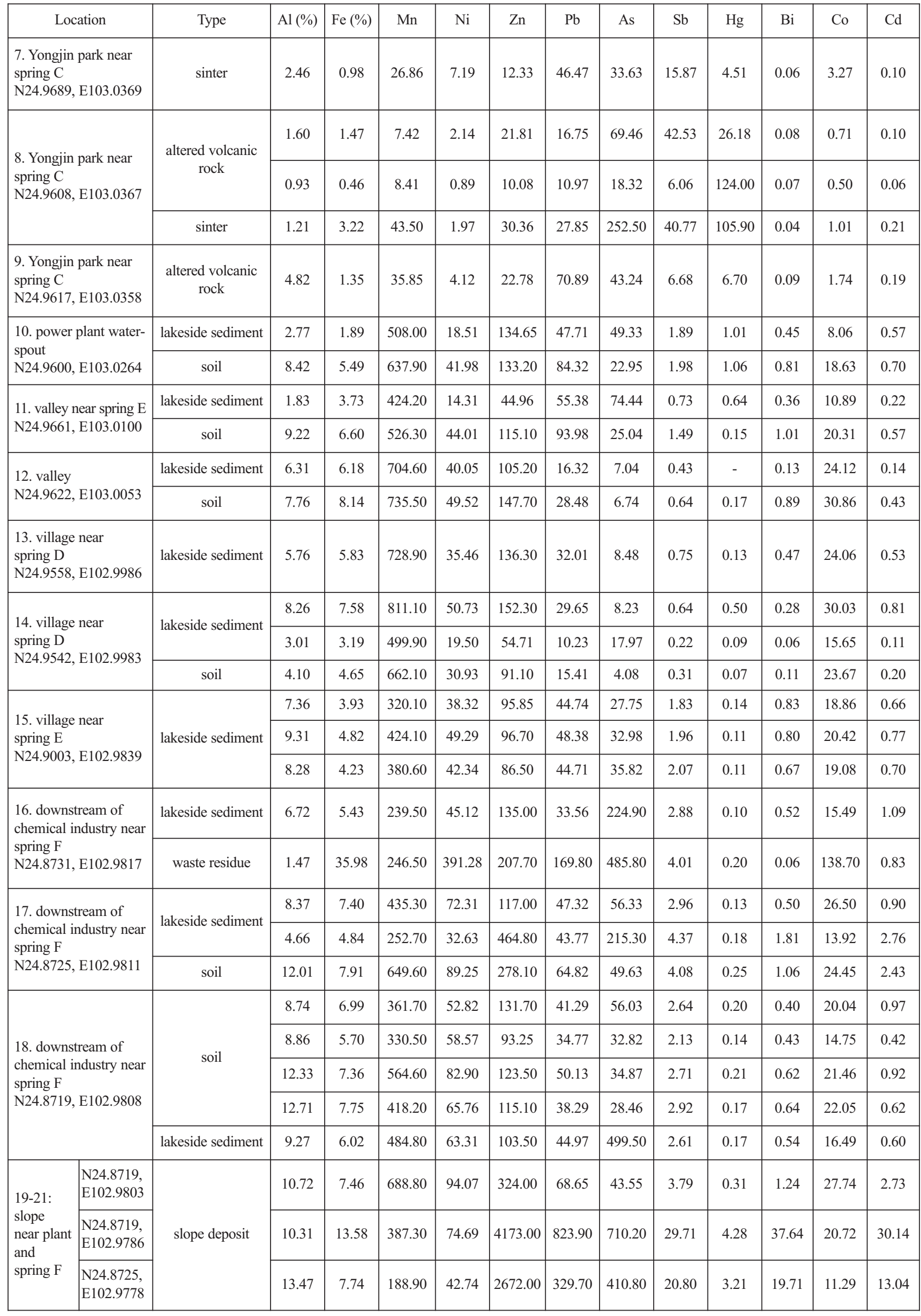


Original data. Continued

\begin{tabular}{|c|c|c|c|c|c|c|c|c|c|c|c|c|c|}
\hline Location & Type & $\mathrm{Al}(\%)$ & $\mathrm{Fe}(\%)$ & $\mathrm{Mn}$ & $\mathrm{Ni}$ & $\mathrm{Zn}$ & $\mathrm{Pb}$ & As & $\mathrm{Sb}$ & $\mathrm{Hg}$ & $\mathrm{Bi}$ & Co & $\mathrm{Cd}$ \\
\hline \multirow{4}{*}{$\begin{array}{l}\text { 22. chemical industry } \\
\mathrm{N} 24.8739, \mathrm{E} 102.9758\end{array}$} & \multirow{3}{*}{ waste residue } & 12.36 & 5.81 & 190.90 & 34.27 & 159.60 & 23.76 & 33.85 & 1.45 & 0.28 & 0.54 & 8.22 & 1.09 \\
\hline & & 6.21 & 8.78 & 184.70 & 24.42 & 1434.00 & 488.00 & 726.20 & 21.86 & 11.71 & 54.43 & 12.26 & 11.64 \\
\hline & & 9.46 & 7.13 & 124.90 & 34.40 & 331.10 & 99.65 & 242.90 & 5.10 & 4.52 & 21.91 & 9.65 & 2.35 \\
\hline & lakeside sediment & 10.53 & 5.94 & 222.40 & 43.44 & 142.70 & 44.97 & 46.62 & 2.64 & 1.31 & 1.72 & 14.92 & 0.91 \\
\hline \multirow{2}{*}{$\begin{array}{l}\text { 23. southernmost of } \\
\text { the lake } \\
\text { N24.8658, E102.9806 }\end{array}$} & lakeside sediment & 2.54 & 1.24 & 150.70 & 9.90 & 44.44 & 11.54 & 34.58 & 0.43 & 0.15 & 0.28 & 4.87 & 0.30 \\
\hline & soil & 3.35 & 1.75 & 220.60 & 15.07 & 63.26 & 17.75 & 29.37 & 0.56 & 0.18 & 0.43 & 6.57 & 0.45 \\
\hline $\begin{array}{l}\text { 24. lake near spring A } \\
\text { N24.9433, E103.0172 }\end{array}$ & lacustrine sediment & 10.42 & 6.75 & 784.40 & 52.03 & 105.50 & 70.06 & 25.13 & 1.63 & 0.18 & 0.79 & 20.92 & 0.41 \\
\hline \multirow{2}{*}{$\begin{array}{l}\text { 25. lake near spring A } \\
\text { N24.9422, E103.0161 }\end{array}$} & \multirow{2}{*}{ lacustrine sediment } & 10.24 & 6.79 & 660.40 & 52.72 & 101.50 & 71.24 & 26.40 & 1.48 & 0.19 & 0.77 & 19.89 & 0.40 \\
\hline & & 10.42 & 6.36 & 608.20 & 58.81 & 110.60 & 46.61 & 21.62 & 1.48 & 0.19 & 0.60 & 24.81 & 0.46 \\
\hline \multirow{2}{*}{$\begin{array}{l}\text { 26. lake near spring E } \\
\text { N24.9005, E102.9830 }\end{array}$} & \multirow{2}{*}{ lacustrine sediment } & 10.49 & 6.32 & 523.10 & 62.22 & 116.50 & 37.69 & 19.40 & 1.33 & 0.16 & 0.49 & 26.84 & 0.52 \\
\hline & & 10.29 & 6.34 & 512.60 & 62.45 & 116.00 & 37.94 & 18.24 & 1.25 & 0.20 & 0.58 & 26.24 & 0.54 \\
\hline $\begin{array}{l}\text { 27. lake near spring D } \\
\text { N24.9550, E102.9980 }\end{array}$ & lacustrine sediment & 10.02 & 5.93 & 532.80 & 60.73 & 122.50 & 40.51 & 19.25 & 1.59 & 0.16 & 0.51 & 25.93 & 0.73 \\
\hline \multirow{3}{*}{$\begin{array}{l}\text { 28. valley near spring B } \\
\mathrm{N} 24.8759 \text {, E103.0099 }\end{array}$} & \multirow{2}{*}{ lakeside sediment } & 1.93 & 2.98 & 158.50 & 20.73 & 31.78 & 18.07 & 55.85 & 0.88 & 0.07 & 0.21 & 9.84 & 0.14 \\
\hline & & 10.00 & 5.58 & 400.70 & 51.47 & 81.60 & 43.68 & 72.03 & 3.46 & 0.11 & 0.58 & 25.45 & 0.27 \\
\hline & soil & 8.28 & 4.66 & 376.80 & 41.10 & 65.50 & 37.85 & 23.39 & 1.61 & 0.07 & 0.55 & 21.27 & 0.24 \\
\hline \multirow{2}{*}{$\begin{array}{l}\text { 29. valley } \\
\text { N24.8689, E103.0067 }\end{array}$} & lakeside sediment & 5.48 & 3.67 & 416.90 & 36.17 & 75.60 & 24.78 & 23.36 & 1.15 & 0.08 & 0.38 & 18.62 & 0.53 \\
\hline & soil & 9.37 & 6.40 & 617.50 & 63.71 & 128.70 & 38.66 & 24.36 & 1.67 & 0.09 & 0.52 & 30.92 & 0.93 \\
\hline \multirow{3}{*}{$\begin{array}{l}\text { 30. valley with spring B } \\
\mathrm{N} 24.8756, \mathrm{E} 103.0086\end{array}$} & lakeside sediment & 6.55 & 7.38 & 824.00 & 47.86 & 111.80 & 20.89 & 69.05 & 1.09 & 0.07 & 0.22 & 28.95 & 0.70 \\
\hline & lacustrine sediment & 9.87 & 11.01 & 1249.00 & 74.91 & 175.30 & 29.33 & 12.09 & 1.18 & 0.14 & 0.40 & 38.64 & 1.37 \\
\hline & soil & 11.52 & 8.96 & 660.30 & 89.49 & 330.10 & 47.98 & 24.76 & 1.84 & 0.12 & 0.53 & 33.60 & 3.61 \\
\hline \multirow{3}{*}{$\begin{array}{l}\text { 31. valley near spring B } \\
\text { N24.8828, E103.0100 }\end{array}$} & \multirow{2}{*}{ lakeside sediment } & 5.65 & 3.59 & 378.40 & 28.38 & 62.36 & 29.80 & 6.89 & 0.56 & 0.04 & 0.28 & 17.49 & 0.22 \\
\hline & & 4.33 & 3.19 & 342.20 & 21.25 & 41.53 & 19.96 & 26.46 & 0.82 & 0.05 & 0.20 & 14.28 & 0.16 \\
\hline & soil & 6.63 & 4.45 & 577.40 & 37.40 & 100.90 & 33.28 & 6.72 & 0.79 & 0.05 & 0.59 & 19.62 & 0.59 \\
\hline
\end{tabular}

\section{Acknowledgements}

This research is supported by the "Fundamental research funds for the central universities" and National natural science foundation of China (40973066).

\section{References}

1. GUNDUZ O., SIMSEK C., HASOZBEK A. Arsenic pollution in the groundwater of Simav Plain, Turkey: its impact on water quality and human health. Water Air Soil Poll. 205, (1-4), 43, 2010.

2. GUO H., WEN D., LIU Z., JIA Y., GUO Q. A review of high arsenic groundwater in Mainland and Taiwan, China: Distribution, characteristics and geochemical processes. Appl. Geochem. 41, 196, 2014.

3. MELAK D., FERRECCIO C., KALMAN D., PARRA R., ACEVEDO J., PEREZ L., CORTES S., SMITH A. H.,
YUAN Y., LIAW J., STEINMAUS C. Arsenic methylation and lung and bladder cancer in a case-control study in northern Chile. Toxicol. Appl. Pharm. 274, (2), 225, 2014.

4. SMEDLEY P. L., KINNIBURGH D. G. A review of the source, behaviour and distribution of arsenic in natural waters. Appl. Geochem. 17, (5), 517, 2002.

5. RIEUWERTS J., MIGHANETARA K., BRAUNGARDT C., ROLLINSON G., PIRRIE D., AZIZI F. Geochemistry and mineralogy of arsenic in mine wastes and stream sediments in a historic metal mining area in the UK. Sci. Total Environ. 472, 226, 2014.

6. NTAKIRUTIMANA T., DU G., GUO J. S., GAO X., HUANG L. Pollution and Potential Ecological Risk Assessment of Heavy Metals in a Lake. Pol. J. Environ. Stud. 22, (4), 1129, 2013.

7. SMEDLEY P. L., KINNIBURGH D. G. Arsenic in Groundwater and the Environment. 279, 2013.

8. FENDORF S., MICHAEL H. A., Van GEEN A. Spatial and temporal variations of groundwater arsenic in South and Southeast Asia. Science. 328, (5982), 1123, 2010. 
9. GIERE R., SIDENKO N., LAZAREVA E. The role of secondary minerals in controlling the migration of arsenic and metals from high-sulfide wastes (Berikul gold mine, Siberia). Appl. Geochem. 18, (9), 1347, 2003.

10. NICKSON R., McARTHUR J., BURGESS W., AHMED K. M., RAVENSCROFT P., RAHMANN M. Arsenic poisoning of Bangladesh groundwater. Nature. 395, (6700), 338, 1998.

11. POLIZZOTTO M. L., KOCAR B. D., BENNER S. G., SAMPSON M., FENDORF S. Near-surface wetland sediments as a source of arsenic release to ground water in Asia. Nature. 454, (7203), 505, 2008

12. GONZALEZ-FERNANDEZ O., QUERALT I., CARVALHO M. L., GARCIA G. Lead, zinc, arsenic and copper pollution in the alluvial plain of a mining wadi: The Beal Case (Cartagena-La Union Mining District, SE Spain). Water Air Soil Poll. 220, (1-4), 279, 2011.

13. HALLI M., SARI E., KURT M. A. Assessment of Arsenic and Heavy Metal Pollution in Surface Sediments of the Ergene River, Turkey. Pol. J. Environ. Stud. 23, (5), 1581, 2014.

14. GALIULIN R., GALIULINA R. Pollution of the territory of Chelyabinsk and the suburbs with arsenic upon coal combustion. Solid Fuel Chemistry. 45, (3), 197, 2011.

15. SAVERY L. C., WISE J. T. F., WISE S. S., FALANK C., GIANIOS C. Jr., THOMPSON W. D., PERKINS C., ZHENG T., ZHU C., WISE J. P., Sr. Global assessment of arsenic pollution using sperm whales (Physeter macrocephalus) as an emerging aquatic model organism. Comparative Biochemistry and Physiology. Toxicology \& pharmacology: CBP. 163, 55, 2014.

16. PETRINI R., SLEJKO F., LUTMAN A., PISON S., FRANCESCHINI G., ZINI L., ITALIANO F., GALIC A. Natural arsenic contamination in waters from the Pesariis village, NE Italy. Environmental Earth Sciences. 62, (3), 481, 2011

17. VERPLANCK P. L., MUELLER S. H., GOLDFARB R. J., NORDSTROM D. K., YOUCHA E. K. Geochemical controls of elevated arsenic concentrations in groundwater, Ester Dome, Fairbanks district, Alaska. Chem. Geol. 255, (1), 160, 2008.

18. BASU A., SCHREIBER M. E. Arsenic release from arsenopyrite weathering: Insights from sequential extraction and microscopic studies. J. Hazard. Mater. 262, 896, 2013.

19. KWON J. C., LEE J.-S., JUNG M. C. Arsenic contamination in agricultural soils surrounding mining sites in relation to geology and mineralization types. Appl. Geochem. 27, (5), 1020, 2012

20. WANG Z., HE B., PAN X., ZHANG K., WANG C., SUN J., YUN Z., JIANG G. Levels, trends and risk assessment of arsenic pollution in Yangzonghai Lake, Yunnan Province, China. Science China Chemistry. 53, (8), 1809, 2010.

21. ZHANG Y., LIU J., CHEN X., SUN J. Arsenic in waters and sediments of Yangzonghai Lake, China. Energy Education Science and Technology Part A-Energy Science and Research. 30, (1), 309, 2012.

22. ZHANG Y., SUN J., LIU J., HUANG G., XIANG X., CHEN X., JING J., CUI H. Heavy Metal Contamination and
Potential Ecological Risk Assessment of Sediments in Yangzonghai Lake. in 2010 International Conference in Digital Manufacturing and Automation (ICDMA). IEEE. 2010.

23. ZHANG Y., XIANG X., ZHANG Y., CHEN X., LIU J., WANG J., ZHANG Y., SUN J. Distribution and sources of arsenic in Yangzonghai Lake, China. Huan Jing Ke Xue. 33, (11), 3768, 2012 [In Chinese].

24. QI J., XU Z., LI X., FANG J., HUANG J. Study on Source and Speciation Distribution Characteristics of Arsenic in Yangzonghai Lake Waters. Journal of Anhui Agricultural Sciences. 20, 123, 2010 [In Chinese].

25. TOMKINS A. G. Wetting facilitates late-stage segregation of precious metal-enriched sulfosalt melt in magmatic sulfide systems. Geology. 38, (10), 951, 2010.

26. BAI J., CUI B., CHEN B., ZHANG K., DENG W., GAO H., XIAO R. Spatial distribution and ecological risk assessment of heavy metals in surface sediments from a typical plateau lake wetland, China. Ecol. Model. 222, (2), 301, 2011.

27. ZAN F., HUO S., ZHANG J., ZHANG L., XI B., ZHANG L. Arsenic fractionation and contamination assessment in sediments of thirteen lakes from the East Plain and Yungui Plateau Ecoregions, China. J. Environ. Sci. 26, (10), 1977, 2014.

28. CHENG H., LI M., ZHAO C., YANG K., LI K., PENG M., YANG Z., LIU F., LIU Y., BAI R., CUI Y., HUANG Z., LI L., LIAO Q., LUO J., JIA S., PANG X., YANG J., YIN G. Concentrations of toxic metals and ecological risk assessment for sediments of major freshwater lakes in China. J. Geochem. Explor. 157, 15, 2015.

29. KUKRER S., ŞEKER S., ABACI Z. T., KUTLU B. Ecological risk assessment of heavy metals in surface sediments of northern littoral zone of Lake Çıldır, Ardahan, Turkey. Environ. Monit. Assess. 186, (6), 3847, 2014.

30. THEVENON F., POTE J. Water pollution history of Switzerland recorded by sediments of the large and deep perialpine lakes Lucerne and Geneva. Water Air Soil Poll. 223, (9), 6157, 2012

31. ZHANG N., WEI C., YANG L. Occurrence of arsenic in two large shallow freshwater lakes in China and a comparison to other lakes around the world. Microchem. J. 110, 169, 2013.

32. DEVESA-REY R., DIAZ-FIERROS F., BARRAL M. T. Assessment of enrichment factors and grain size influence on the metal distribution in riverbed sediments (Anllons River, NW Spain). Environ. Monit. Assess. 179, (1-4), 371, 2011.

33. HO H. H., SWENNEN R., CAPPUYNS V., VASSILIEVA E., VAN TRAN T. Necessity of normalization to aluminum to assess the contamination by heavy metals and arsenic in sediments near Haiphong Harbor, Vietnam. J. Asian Earth Sci. 56, 229, 2012.

34. SHI G.-L., TIAN Y.-Z., GUO C.-S., FENG Y.-C., XU J., ZHANG Y. Sediment-pore water partition of PAH source contributions to the Yellow River using two receptor models. Journal of Soils and Sediments. 12, (7), 1154, 2012.

35. VAROL M., ŞEN B. Assessment of nutrient and heavy metal contamination in surface water and sediments of the upper Tigris River, Turkey. Catena. 92, 1, 2012. 
